\title{
Potential Vector Shelter for Malaria in South Central Timor Regency in Indonesia
}

\author{
Nisa Fauziah, ${ }^{1,2}$ Arie Galih Mohamad, ${ }^{3}$ Naufal Fakhri Nugraha, ${ }^{3}$ Lia Faridah, ${ }^{1}$ Jontari Hutagalung ${ }^{4}$ \\ ${ }^{1}$ Parasitology Division, Department of Basic Medical Sciences, Faculty of Medicine, Universitas Padjadjaran, \\ Indonesia, ${ }^{2}$ Program Study of Clinical Parasitologist, Faculty of Medicine, Universitas Indonesia, Jakarta, \\ Indonesia, ${ }^{3}$ Faculty of Medicine, Universitas Padjadjaran, Indonesia, ${ }^{4}$ Laboratory of Parasitology, Center \\ for Biomedical and Basic Health Technology, National Institute of Health Research and Development, \\ Ministry of Health, Indonesia
}

\begin{abstract}
More than half of the areas in East Nusa Tenggara province, a province in the eastern part of Indonesia, are planned to be free from malaria by the end of 2030. However, one of the critical indicators for malaria elimination is still lacking, i.e. vectors' environment and breeding place indicators. South Central Timor (SCT) District is one of the areas with the highest Annual Parasite Incidence (API) $>2 \%$ with the majority of the population works as farmers. The purpose of this study was to capture the relationship between environmental factors and the prevalence of malaria. This study was a cross-sectional analytic retrospective study using data from a previous malaria study conducted in August 2013 to September 2014 in 5 sub-districts of SCT district. All respondents were selected using the systematic random sampling approach from the population of healthy people. Data were collected using a standard questionnaire and an observation environment form. Malaria was confirmed through microscopic and Polymerase Chain Reaction (PCR) examinations. Data were then analyzed using the bivariate and multivariate analysis with 95\% CI and $\alpha: 0.05$. Of 357 data collected, 35\% (125/357) were malaria positive based on PCR examination. Two variables (living nearby lagoon and nearby rice field) were significant ( $p$-value $<0.05$ ) as vector shelters for Anopheles sp. Thus, these have to be included as inputs to formulate effective and efficient malaria elimination strategies and programs in 2030.
\end{abstract}

Keywords: Malaria prevalence, South Central Timor Regency, vector shelter

\section{Lokasi Potensial Perkembangbiakan Vektor Malaria di Kabupaten Timor Tengah Selatan, Indonesia}

\begin{abstract}
Abstrak
Lebih dari setengah Provinsi Nusa Tenggara Timur di Indonesia timur akan menghadapi bebas malaria pada akhir tahun 2030. Namun, salah satu indicator penting untuk eliminasi malaria adalah pengukuran lingkungan dan tempat berkembang biak vector masih kurang. Kabupaten Timor Tengah Selatan adalah daerah dengan salah satu Insidensi Parasit Tahunan tertinggi di Indonesia dan mayoritas penduduknya bekerja sebagai petani. Tujuan dari penelitian ini adalah mencari hubungan antara faktor lingkungan dengan prevalensi malaria. Penelitian ini menggunakan studi potong lintang metode analitik, menggunakan data retrospektif dari penelitian sebelumnya yang dilakukan pada Agustus 2013 hingga September 2014 di 5 kecamatan di Kabupaten Timor Tengah Selatan. Responden dipilih secara acak sistematik dari orang sehat. Pengumpulan data dengan kuesioner standar dan formulir observasi lingkungan. Konfirmasi malaria dengan menggunakan metode mikroskopis dan PCR. Data dianalisis dengan bivariat dan multivariate dengan 95\% CI dan $\alpha$ : 0,05. Total 357 data dikumpulkan, 35\% (125/357) positif malaria dengan pemeriksaan PCR. Dua variabel (dekat dengan laguna dan dekat dengan sawah) signifikan (nilai-p $<0,05$ ) sebagai tempat perlindungan vector untuk Anopheles sp. Penelitian ini diharapkan dapat memberikan informasi rinci untuk merumuskan strategi dan program eliminasi malaria pada tahun 2030 yang efektif dan efisien.
\end{abstract}

Kata kunci: Kabupaten Timor Tengah Selatan, prevalensi malaria, perkembangbiakan vektor

Corresponding Author: Lia Faridah, Parasitology Division, Department of Basic Medical Sciences, Faculty of Medicine, Universitas Padjadjaran, Jalan Prof. Eyckman No. 38 Bandung, West Java, Indonesia, Email: lia.faridah@unpad.ac.id 


\section{Introduction}

Malaria is transmitted through the bite of female Anopheles sp. mosquitoes that contain malaria parasites. In Indonesia, $72 \%$ of the population live in areas that are free from malaria. However, there are still $10.7 \%$ of Indonesian people who live in medium and high endemic areas, such as Papua, West Papua, and East Nusa Tenggara. These three provinces are the ones that contribute the most to malaria cases in the country. ${ }^{1}$

Malaria elimination has been announced by the Ministry of Health, Republic of Indonesia in a formal regulation since 2009. Currently, the targets for elimination are, chronologically, Jakarta and Bali in 2010; Java, Aceh, and Riau in 2015; Sumatera, Kalimantan, Sulawesi, and West Nusa Tenggara in 2020, and Papua, West Papua, Maluku, East Nusa Tenggara and North Maluku in 2030. ${ }^{2}$ Some of the most critical indicators for malaria elimination is the measurement of the environment and breeding place of the vectors. Both of these assessments are important for reducing the source of the vector by applying environmental management. ${ }^{3}$ Given the archipelago geography of Indonesia, unique challenges are to be expected for source reduction program. ${ }^{4}$

East Nusa Tenggara province, which is located in the eastern part of Indonesia, has 22 districts with $5,203,514$ population in 2017. ${ }^{5}$ According to the Annual Parasite Incidence (API) in 2017, East Nusa Tenggara province is the $3^{\text {rd }}$ province with the highest malaria cases in Indonesia (API $=5.76 \% 0)^{4}$

South Central Timor District is one of the districts in East Nusa Tenggara province that consists of 32 sub-districts that lie on a 3,995.56 $\mathrm{km}^{2}$ area with 461,681 population. ${ }^{5}$ The district has the highest API value, with a total of 12,527 malaria cases. ${ }^{4}$

More than $60 \%$ of South Central Timor District is dominated by hills and valleys, surrounded by highlands or hills of the island. There are 40 rivers with a length of ranging from \pm 25 up to 118 $\mathrm{km}$. The area have two seasons: the dry season in June-September and the rainy season in OctoberMarch. The wind currents from Australia and the Pacific Ocean do not contain a lot of water vapor, resulting in the dry climate of the area. ${ }^{5}$

Eastern Indonesia environment, with the vegetation and temperature ranging from 30 $31^{\circ} \mathrm{C}$, supports the breeding of Anopheles sp. mosquitoes. ${ }^{5}$ Temperature affects the level of dissolved oxygen in water essential for the survival of this mosquito larvae. ${ }^{6,7}$

Reliable information is required regarding the relationship between malaria and environmental factors to maximize public benefits and help the District Health Office (DHO) in developing the 2030 malaria-free program. Unfortunately, the environmental assessment related to the malaria prevalence, especially in eastern Indonesia, is still lacking. The purpose of this study was to capture the relationship between the environmental factors related to shelter vectors and the prevalence of malaria. This study was expected to provide detailed information to formulate effective and efficient malaria elimination strategies and programs in facing the year of 2030 .

\section{Methods}

This was a cross-sectional analytic retrospective study using secondary data from the previous malaria study conducted in August 2013 to September $2014 .^{8}$ This study was conducted in 5 sub-districts in South Central Timor District, East Nusa Tenggara Province, Indonesia based on their API, i.e. South Amanatun (API $>5 \%$ ), Central Amanuban (API $>5 \%$ ) , South Amanuban (API 1-5\%), Batu Putih (API 1-5\%o), and Oenino (API $<1 \%$ ).

Respondents were recruited through a systematic random sampling based on households from each sub-district in South Central Timor District, East Nusa Tenggara Province. A total of 357 subjects were recruited based on the inclusion criteria of $>14$ years old, healthy based on the assessment local health practitioner before the study, and no fever $\left(>38^{\circ} \mathrm{C}\right)$. The sample size was calculated using a formula for analytic comparative study with a categorical scale $(\alpha=5 \%$ and $\beta=20 \%)$ with a significant difference in the minimum proportion of malaria $\left(\mathrm{p}_{1}-\mathrm{p}_{2}\right)$ of 0.2 . Based on the calculation, the minimum representative sample size of this study was 212. Eleven environment variables were analyzed in this study: living nearby river, lagoon, rice fields, garden, swamp edge, and water spring; water source from plumbing; water source from wells or springs; family owns lands or rice fields; family owns livestock; and livestock nearby house. To reduce bias in the environmental assessment, a standard questionnaire, i.e. malaria observation form, and double assessment (local and main investigator team members) were applied. Malaria was confirmed using results from microscopic 


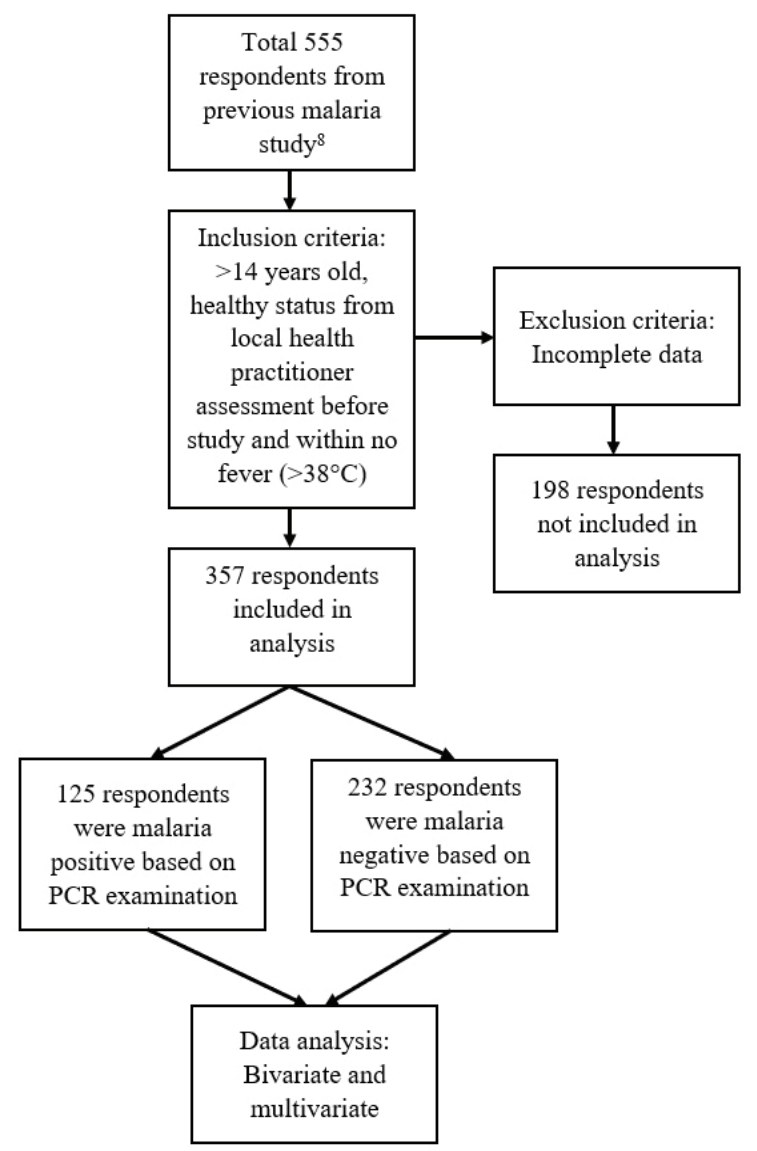

Figure Study Flowchart examination and Polymerase Chain Reaction (PCR).

The predetermined variables were analyzed using the 25 th version IBM $®$ SPSS $®$ software application. The obtained variables were then processed using chi-square and multivariate analysis with a confidence interval of $95 \%$, with a p-valuse of 0.05 considered significant. Results were then presented in table form, with a p-value of $>0.05$ represented the lack of significance while a p-value $<0.05$ indicated significance.

This study received ethical approval from the Health Research Ethics Commitee, Faculty of Medicine, Universitas Padjadjaran, under the issuance of the ethical clearance number 1100/ UN6.KEP/EC/2019. All respondent data were analyzed anonymously.

\section{Results}

A total of 357 subjects were recruited based on the inclusion criteria and exclusion criteria in this study. Of these, 35\% (125/357) were malaria positive based on PCR examination.

Table 1 shows that there were more female respondents than male respondents in the positive PCR results group and the negative PCR results group. From the perspective of age, the group with the highest positive cases in PCR results was $>50$ years old group respondents

Table 1 Respondent Characteristics $(\mathrm{N}=357)$

\begin{tabular}{|c|c|c|c|}
\hline \multirow{2}{*}{ Characteristics } & \multicolumn{2}{|c|}{ PCR examination } & \multirow[t]{2}{*}{ Total (\%) } \\
\hline & Positive (\%) & Negative (\%) & \\
\hline \multicolumn{4}{|l|}{ Gender } \\
\hline Male & $51(40.8)$ & 91 (39.2) & $142(39.8)$ \\
\hline $\begin{array}{l}\text { Female } \\
\text { Age Groups }\end{array}$ & $74(59.2)$ & $141(60.8)$ & $215(60.2)$ \\
\hline $14-15$ years & $1(0.8)$ & $6(2.6)$ & $7(2.0)$ \\
\hline $16-20$ years & $4(3.2)$ & $6(2.6)$ & $10(2.8)$ \\
\hline $21-30$ years & 13 (10.4) & 36 (15.5) & 49 (13.7) \\
\hline $31-40$ years & $34(27.2)$ & 67 (28.9) & $101(28.3)$ \\
\hline $41-50$ years & $27(21.6)$ & $56(24.1)$ & $83(23.2)$ \\
\hline $\begin{array}{l}>50 \text { years } \\
\text { Districts }\end{array}$ & $46(36.8)$ & $61(26.3)$ & $107(30.0)$ \\
\hline South Amanatun & 21 (16.8) & $61(26.3)$ & $82(23.0)$ \\
\hline Central Amanuban & $36(28.8)$ & 41 (17.7) & 77 (21.6) \\
\hline South Amanuban & $5(4.0)$ & $19(8.2)$ & $24(6.7)$ \\
\hline BatuPutih & $30(24.0)$ & $46(19.8)$ & 76 (21.3) \\
\hline Oenino & $33(26.4)$ & $65(28.0)$ & $98(27.5)$ \\
\hline
\end{tabular}

Note: PCR= Polymerase Chain Reaction 
Table 2 Bivariate Analysis on Effect of Mosquito Breeding Types on Malaria Prevalence $(n=375)$

\begin{tabular}{|c|c|c|c|c|c|c|}
\hline \multirow[b]{2}{*}{ Variables } & \multicolumn{2}{|c|}{ Malaria Status } & \multirow{2}{*}{$\begin{array}{l}\text { Total } \\
(\%)\end{array}$} & \multirow{2}{*}{$\begin{array}{l}\text { P-value } \\
\text { (OR) }\end{array}$} & \multicolumn{2}{|c|}{$95 \% \mathrm{CI}$} \\
\hline & $\begin{array}{l}\text { Positive } \\
\text { (\%) }\end{array}$ & $\begin{array}{l}\text { Negative } \\
\text { (\%) }\end{array}$ & & & Lower & Upper \\
\hline \multicolumn{7}{|l|}{ Nearby river $(<50 \mathrm{~m})$} \\
\hline Yes & $19(15.2)$ & $36(15.5)$ & $55(15.4)$ & 0.937 & \multirow{2}{*}{0.533} & \multirow{2}{*}{1.785} \\
\hline No & $106(84.8)$ & $196(84.5)$ & $302(84.6)$ & $(0.976)$ & & \\
\hline \multicolumn{7}{|c|}{ Nearby lagoon $(<50$ m) } \\
\hline Yes & $1(0.8)$ & $19(8.2)$ & $20(5.6)$ & 0.004 & \multirow{2}{*}{0.012} & \multirow{2}{*}{0.684} \\
\hline No & 124 (99.2) & $213(91.8)$ & $337(94.4)$ & $(0.09)$ & & \\
\hline \multicolumn{7}{|c|}{ Nearby rice field $(<50 \mathrm{~m}\}$} \\
\hline Yes & $18(14.4)$ & $16(6.9)$ & $34(9.5)$ & 0.021 & \multirow{2}{*}{1.114} & \multirow{2}{*}{4.629} \\
\hline No & $107(85.6)$ & $216(93.1)$ & $323(90.5)$ & $(2.271)$ & & \\
\hline \multicolumn{7}{|c|}{ Nearby garden $(<50 \mathrm{~m})$} \\
\hline Yes & $62(49.6)$ & $118(50.9)$ & $180(50.4)$ & 0.820 & \multirow{2}{*}{0.615} & \multirow{2}{*}{1.469} \\
\hline No & $63(50.4)$ & $114(49.1)$ & $177(49.6)$ & $(0.951)$ & & \\
\hline \multicolumn{7}{|c|}{ Nearby swamp edge $(<50 \mathrm{~m})$} \\
\hline Yes & $18(14.4)$ & $28(12.1)$ & $46(12.9)$ & 0.531 & \multirow{2}{*}{0.648} & \multirow{2}{*}{2.317} \\
\hline No & $107(85.6)$ & $204(87.9)$ & $311(87.1)$ & $(1.226)$ & & \\
\hline \multicolumn{7}{|c|}{ Nearby water spring $(<50 \mathrm{~m})$} \\
\hline Yes & $2(1.6)$ & $6(2.6)$ & $8(2.2)$ & 0.548 & \multirow{2}{*}{0.122} & \multirow{2}{*}{3.080} \\
\hline No & $123(98.4)$ & $226(97.4)$ & $349(97.8)$ & $(0.612)$ & & \\
\hline \multicolumn{7}{|c|}{ Water source from plumbing } \\
\hline Yes & $9(7.2)$ & $22(9.5)$ & $31(8.7)$ & 0.465 & \multirow{2}{*}{0.330} & \multirow{2}{*}{1.661} \\
\hline No & $116(92.8)$ & $210(90.5)$ & $326(91.3)$ & $(0.741)$ & & \\
\hline \multicolumn{7}{|c|}{$\begin{array}{l}\text { Water source from wells/ } \\
\text { springs }\end{array}$} \\
\hline Yes & $94(75.2)$ & $172(74.1)$ & $266(74.5)$ & 0.826 & \multirow{2}{*}{0.641} & 1716 \\
\hline No & $31(24.8)$ & $60(25.9)$ & $91(25.5)$ & (1.058) & & $1 . / 40$ \\
\hline Family owns land/ric & & & & & & \\
\hline Yes & $95(76.0)$ & $177(76.3)$ & $272(76.2)$ & 0.951 & 0501 & \\
\hline No & $30(24.0)$ & 55 (23.7) & $85(23.8)$ & $(0.984)$ & 0.591 & 1.639 \\
\hline Family owns livestoc & & & & & & \\
\hline Yes & $97(77.6)$ & $188(81.0)$ & $285(79.8)$ & 0.440 & 0.476 & 1.382 \\
\hline No & $28(22.4)$ & $44(19.0)$ & $72(20.2)$ & $(0.811)$ & & \\
\hline Livestock nearby hol & & & & & & \\
\hline Yes & $94(75.2)$ & $181(78.0)$ & $275(77.0)$ & 0.546 & & \\
\hline No & $31(24.8)$ & $51(22.0)$ & $82(23.0)$ & $(0.854)$ & 0.512 & 1.425 \\
\hline
\end{tabular}

Note: PCR= Polymerase Chain Reaction; OR= Odd Ratio;, 95\% CI= 95\% Confidence Interval 
Table 3 Multivariate Analysis of Influence of Mosquito Breeding Type on Malaria Prevalence

\begin{tabular}{|c|c|c|c|c|c|}
\hline \multirow{2}{*}{ Variable } & \multirow{2}{*}{$\boldsymbol{\beta}$} & \multirow{2}{*}{ P-value } & \multirow{2}{*}{ OR } & \multicolumn{2}{|c|}{ 95\% CI } \\
\hline & & & & Lower & Upper \\
\hline Nearby Lagoon $(<50 \mathrm{~m})$ & -2.325 & 0.024 & 0.098 & 0.013 & 0.741 \\
\hline Nearby Rice Field $(<50 \mathrm{~m})$ & 0.738 & 0.043 & 2.091 & 1.024 & 4.268 \\
\hline
\end{tabular}

Note: OR= Odd Ratio; 95\% CI= 95\% Confidence Interval

while the group of $<15$ years old had the least positive cases. On the other hand, the highest negative case group was seen in the 31-40 age group while the group with the least negative cases was the $<15$ year and the 16-20 year groups. Based on the sub-district area, the Central Amanuban sub-district had the highest positive malaria cases with 36 cases and the Oenino sub-district was the sub-district with the least malaria cases.

Table 2 shows the results of data analysis using the chi-square test from the eleven variables studied. The nearby lagoon variable and nearby rice field variable showed a p-value of $<0.05$, meaning that there was a significant relationship between these variables and the prevalence of malaria.

Table 3 explains the results of the multivariate analysis. Two significant variables had p-values below 0.025 . It showed that the nearby lagoon variable $(<50 \mathrm{~m})$ had a p-value of 0.024 , lower than the nearby rice field variable $(<50 \mathrm{~m})$ with a $\mathrm{p}$-value of 0.043 . However, the odds ratio showed that the nearby lagoon variable $(<50 \mathrm{~m})$ is not significant, only with an odds ratio of 0.098 . This result is the opposite of the variable of a nearby rice field $(<50 \mathrm{~m})$, which significantly increased the risk to two times higher, with an odds ratio of 2.091 .

\section{Discussion}

This study discovered that the rice field is the vector shelter, which is significant for malaria transmission in South Central Timor District when compared to other conditions. A survey conducted in Nunukan District, East Kalimantan, reveal a significant effect of the proximity between houses and breeding places of malaria vectors (rice fields) with malaria prevalence with a p-value of $0.002 .{ }^{9}$ This is in contrast with a study conducted by Hasyimi, stating that the proximity between houses and breeding places (rice field) has no significant effect on malaria prevalence, with a p-value of $0.766 .^{10}$
The presence of rice fields around the home environment will increase the potential for malaria as the fields will be inundated with water, which is a very good breeding site for Anopheles sp. ${ }^{11}$ Furthermore, wide areas will provide a wide media for Anopheles sp. breeding. It will make it easier to increase the population and will be more challenging to control. One of the control efforts that can be applied by the surrounding community is to add mosquito larvae fish-eaters such as mujair fish in rice fields and plant rice simultaneously so that the removal of breeding sites can be more manageable. ${ }^{12}$

The potential Anopheles sp. breeding places are also found in coastal areas, such as lagoons, rivers, and rice paddies near the coastal line. It further proves that Anopheles vagus is the most potential malaria vector in these sites. Anopheles vagus is one of the most frequently captured mosquitos which may be due to the fact that it is found in almost all types of breeding places including lagoons, rice fields, rivers, and stagnant water. ${ }^{13}$

A study in Africa also supports these findings. The study proves the close link between malaria vectors and agriculture by discovering that gravid Anopheles arabiensis are attracted and oviposit in response to the odor in the air around rice fields. ${ }^{14}$ A study conducted by Widawati in East Nusa Tenggara had discovered that Anopheles annularis is the most commonly found Anopheles in the lowlands whereas Anopheles vagus is more commonly found in the highlands of East Nusa Tenggara Province. ${ }^{15}$

The environmental conditions are different for each endemic area, and it becomes locally unique for local governments to intervene in dealing with malaria. A study conducted in Nunukan District, East Kalimantan, found that the presence of livestock near homes does not have a significant effect on malaria prevalence with a p-value of $0.217 . .^{9}$ This is similar to the finding in this study, with a p-value of 0.44 for livestock near home. In a study in the Toho Village, Pontianak District, the p-value identified is $0.004 .{ }^{16}$ However, other studies in Kei Besar 
Sub-District, Southeast Maluku District, Maluku Province show that the livestock presence near the house significantly affect malaria prevalence with a p-value of $0.021 .^{17}$

The fact is that most of the population in South Central Timor are farmers, and the study findings emphasizes the reasons why this area is endemic for malaria. ${ }^{5}$ Women suffer more from malaria than men because apart from being a farmer, women do their household activities since morning. This situation puts women at greater risk of malaria infection than men because Anopheles bites human from dusk to dawn. Meanwhile, the socio-economic condition also takes part in the prevalence. The contradictory belief that women are responsible for their children's health but the men control the funds has been emphasized. In this case, delays in decision making may happen when the spouse (or other male decision-makers) is absent. ${ }^{18,19}$

This study uses secondary data. Therefore, the variables for analysis are limited. Additional variables are needed so that the results obtained are more varied and to be able to better prove the effect of environmental conditions on malaria prevalence. Also, this study did not collect mosquitoes. As a result, this no link can be identified between topography and the species of Anopheles.

In conclusion, the rice fields are used as the shelter by malaria vector and is a variable that is significant for malaria transmission in South Central Timor District, compared to other conditions. Since women suffer more than men, health officials must look at ways of addressing women's relative lack of power and financial resources. Equally important is the need to target women for malaria control education and sensitization. Subsequently, a collaboration among health practitioners, local institutions, and the community is required for preventing malaria infection. The local institutions should focus on this matter and help develop more convincing recommendations for preventing malaria infection. The community also needs to increase their knowledge and proactiveness in efforts to prevent malaria, such as getting used to using mosquito nets and anti-mosquito repellent; minimizing outdoor activities at night; wearing clothes with long sleeves, etc. ${ }^{20}$

\section{References}

1. Kemenkes RI. Riset kesehatan dasar 2018. Jakarta: Badan Penelitian dan Pengembangan
Kesehatan Kementerian Kesehatan Republik Indonesia; 2018.

2. Kemenkes RI. Buletin jendela data dan informasi kesehatan: epidemiologi malaria di Indonesia. Jakarta Kementrian Kesehat RI. 2011;

3. Sugiarto S, Hadi UK, Soviana S, Hakim L, Ariati J. Indikator entomologi dalam pengendalian vektor terpadu (PVT) menuju eliminasi malaria di Kabupaten Nunukan, Kalimatan Utara. J Ekol Kesehat. 2018;17(2):114-22.

4. Kemenkes RI. Profil kesehatan indonesia tahun 2017. Jakarta: Kementerian Kesehatan Republik Indonesia; 2018.

5. East Nusa Tenggara Province Communication and Information Office: Geographical condition [Internet]. 2018. Available from: http://nttprov.go.id/2018/index.php/ profil/kondisi-geographic.

6. Mading M, Kazwaini M. Ekologi anopheles spp. di Kabupaten Lombok Tengah. Aspirator J Vector-Borne Dis. 2014;6(1):13-20.

7. Ernawati K, Achmadi UF, Soemardi TP, Thayyib H. Tambak terlantar sebagai tempat perindukan nyamuk di daerah endemis malaria (penyebab dan penanganannya). J Ilmu Lingkung. 2012;10(2):54-63.

8. Jontari H, Kusnanto H, Supargiyono S, Hamim SA, Satyagraha AW, Novijanti N, et al. Malaria pre-elimination assessment in Eastern Indonesia. OSIR J. 2016;9(1):1-7.

9. Trapsilowati W, Pujiyanti A, Negari KS. Faktor risiko perilaku dan lingkungan dalam penularan malaria di Pulau Sebatik, Kabupaten Nunukan, Kalimantan Timur. Balaba J Litbang Pengendali Penyakit Bersumber Binatang Banjarnegara. 2016; 12(2):99-110.

10. Hasyimi M, Herawati MH. Hubungan faktor lingkungan yang berpengaruh terhadap kejadian malaria di wilayah timur Indonesia (Analisis Data Riskesdas 2010). Indones J Heal Ecol. 2012;11(1):79861.

11. Nababan R, Umniyati SR. Faktor lingkungan dan malaria yang memengaruhi kasus malaria di daerah endemis tertinggi di Jawa Tengah: analisis sistem informasi geografis. Ber Kedokt Masy. 2018;34(1):11-8.

12. Budiyanto A, Ambarita LP, Salim M. Konfirmasi Anopheles sinensis dan Anopheles vagus sebagai vektor malaria di Kabupaten Muara Enim Provinsi Sumatera Selatan. ASPIRATOR-Journal Vector-borne Dis Stud. 2017;9(2):51-60.

13. Maksud M. Aspek perilaku penting anopheles vagus dan potensinya sebagai 
vektor malaria di Sulawesi Tengah: Suatu telaah kepustakaan. J Vektor Penyakit. 2017;10(2):33-8.

14. Wondwosen B, Birgersson G, Seyoum E, Tekie $\mathrm{H}$, Torto B, Fillinger U, et al. Rice volatiles lure gravid malaria mosquitoes, Anopheles arabiensis. Sci Rep. 2016;6(1):1-8.

15. Widawati M. Perbedaan dataran tinggi dan dataran rendah terhadap keberagaman spesies Anopheles spp. di Provinsi Nusa Tenggara Timur. ASPIRATOR-Journal Vectorborne Dis Stud. 2018;10(2):103-10.

16. Sari A, Sucipto CD, Hajimi H. Faktor determinan kejadian malaria di Kecamatan Toho Kabupaten Pontianak. J Med (Media Inf Kesehatan). 2014;1(1):1-13.

17. Bagaray EF, Umboh JML, Kawatu PAT. Hubungan antara faktor faktor risiko dengan kejadian malaria di Kecamatan KEI Besar Kabupaten Maluku Tenggara Provinsi Maluku. J Media Kesehat. 2015;3:7.

18. Rahmawati E, Hadi UK, Soviana S. Keanekaragaman jenis dan perilaku menggigit vektor malaria (Anopheles spp.) di Desa Lifuleo, Kecamatan Kupang Barat, Kabupaten Kupang, Nusa Tenggara Timur. J Entomol Indones. 2015;11(2):53.

19. Ricci F. Social implications of malaria and their relationships with poverty. Mediterr J Hematol Infect Dis. 2012;4(1):1-10.

20. Alami R, Adriyani R. Tindakan pencegahan malaria di Desa Sudorogo Kecamatan Kaligesing Kabupaten Purworejo. J Promkes Indones J Heal Promot Heal Educ. 2016;4(2):199-211. 